\title{
FURTHER HIDDEN MANUSCRIPTS
}

Three years ago this journal carried an article in which I made a case that all early-nineteenth-century stories from Ireland that involved the finding of concealed manuscripts were in some measure doubtful, some of them seriously so. ${ }^{1}$ A further example escaped me. This is found in James Hardiman's list of his own manuscripts, drawn up when he was seeking to sell the collection in 1832. ${ }^{2}$ The manuscript in question is now BL MS Egerton 88, an important book dating from the late sixteenth century, which Hardiman describes in these terms:

A vellum MS. transcribed in the 11th century, inclosed in an oak case, containing Brehon laws, Historical treatises of the early Irish, \&c. This is one of our most ancient and valuable MSS. It formerly belonged to Archdeacon Mahon, from whom General Vallancey, who alluded to it in his Collection, had the loan of it. I bought it from Doctor Mahon's sister, for $£ 20$; she told me her Brother found it and other documents in the wall of an old Abbey, of which I forget the name, in the County of Roscommon. Quarto. This case also contains three conveyances of lands in the Reign of Henry III, Edward I, and Henry VI, Kings of England. $\backslash 180$ pages, quarto, Irish./

Little if any trust can be placed in his memory. Arthur Mahon (1716-1788) was archdeacon of Elphin, which may have led Hardiman to think of Co.

Roscommon. When the book was still in Mahon's hands, transcripts of law tracts were made from it at Major Vallancey's behest, not later than May 1774, by Muiris Ó Gormáin. ${ }^{3}$ These are now in the Royal Irish Academy, MS 23 Q 12 (cat. 1245), pp. 444-(613), entitled 'Fragment of the Brehon Laws, vol. 13, in the possession of Archdeacon Mahon'. There was no mention then of its mural provenance. William O'Sullivan sought to trace the descent of the book further back. ${ }^{4}$ Arthur Mahon was the son of Peter Mahon (d. 1739), dean of Elphin, who in 1724 had a number of legal manuscripts. ${ }^{5}$ If any of these passed from father to son, then the finding would have to be pushed back beyond Mahon's sister's memory. And Hardiman's claim to have bought the book from a sister is surely impossible. As O'Sullivan pointed out, one of the sisters died in 1791, the other a decade earlier, and Hardiman was born only in 1782. The oak case was itself explained by Hardiman in a note fastened inside it: 'This Box was made out of a piece of old Irish oak from the Roof of St Patrick's Church Dublin in 1818 [. . .]', and across the end, 'These are the MSS lent by Archdeacon Mahon to Vallancey. See Collect. V. I. I got them from the

\footnotetext{
${ }^{1}$ R. Sharpe, 'Medieval manuscripts from Bonamargy and other hidden manuscripts', Studia Hibernica 41 (2015), 49-85.

21832 Hardiman 14, RIA MS 12 M 1 (cat. 1113). This catalogue will be printed in my work on Irish Manuscript Sales (forthcoming).

${ }^{3}$ C. Vallancey, Collectanea de rebus Hibernicis, i. 130, in the advertisement to the second fascicule, dated 20 May 1774, 'The editor takes this opportunity of acknowledging his obligations to Archdeacon Mahon for the fragments of a valuable code of the Brehon laws'.

${ }^{4}$ W. O'Sullivan, 'The Book of Domhnall Ó Duibhdábhoireann, provenance and codicology', Celtica 23 (1999), 276-99.

${ }^{5}$ H. Cotton, Fasti Ecclesiae Hibernicae (Dublin, 1847-51), iv. 136, 142; W. Nicolson, Irish Historical Library (Dublin, 1724), 245.
} 
Archdeacon's sister, \& had this Box made for them'. The year 1818 is a credible date for Hardiman's purchase. His note was retained when the manuscript, boxed 'in loose and confused sheets', was put into order for binding in 1849 by Eugene O'Curry. ${ }^{6}$ If we allow the possibility of Hardiman's buying from a neice or daughter of Mahon, it is certain that the oak case was not associated with immuring and evident that 'the wall of an old Abbey' enters the picture only in describing the collection for sale in 1832.

The story is very similar to that associated in a nineteenth-century label with BL MS Add. 11809, which I discussed in the article. The entry among the index-cards that lie behind the NLI's on-line Sources catalogue, a valuable resource, suggests that this manuscript was known in Dublin a decade earlier than its appearance in London in 1841. The evidence for this is illusory. MS Add. 11809 was supposedly found 'in an inside Wall about 14 feet thick, in the Hoar Abby at Cashell', though its history is entirely unknown before it turned up in the hands of a London bookseller. ${ }^{7}$ TCD MS 2068, given to the library in 1926, has a note at the front, 'Copied from an old Irish manuscript found built up in a wall of Hoare Abbey in the County of Limerick with a translation of part of the same, by James McQuige'. The similarity of these notes led to the hasty suggestion that McQuige was copying from Add. $11809 .{ }^{8}$ The date given c. 1830 does not derive from the manuscript itself, and it is in any case somewhat late for James McQuige, who was active between 1789 and $1828 .{ }^{9}$ A comparison of the contents of TCD MS 2068 and Add. 11809 reveals no overlap at all. The content of MS 2068 must be compared with NLI MS G 36, pp. 102, 106, 112, and 113, texts with translations made by McQuige for his patron Adam Clarke (1762-1832). The exemplar from which the Irish texts in NLI MS G 36 were copied is a medieval book, then owned by Adam Clarke, now NLI MS G 9, fols. 5rb, 5vb, 7ra, and 7rb. This old book, whose scribe was identified by Nessa Ní Shéaghdha as Uilliam Mac an Lega, late fifteenth century, was surely the exemplar referred to in the note. McQuige was well aware that it was old. A recent note at the front said (with much crossing out), 'This manuscript was wrote in the Tenth Century and consists of prayers to various Irish saints and to the Virgin Mary'. Below this McQuige wrote: 'When written I cannot tell, but it must be very ancient: there are Contractions in it which I meet in no other Manuscript; and the spelling, tho' very uniform, yet varies some times, is very simple, differing much from the standard now. And I think better because simpler. There is no Prayer to the Virgin, or any other Saint in it - but one. It all consists of Fragments of very old History, some Lives, and a few Essays. James Mc Quige'. The book was in the hands of

\footnotetext{
${ }^{6}$ Sir Frederic Madden, keeper of manuscripts, had the note pasted at the front of the newly bound book in October 1849 and signed his explanation of it.

${ }^{7}$ Sharpe, 'Medieval manuscripts from Bonamargy', 79-80.

${ }^{8}$ The Sources entry for TCD MS 2068 reads: 'Copy, with English translation, by James M'Quige of part of a life of St George and other religious tracts in Irish, from a manuscript (now BM Add. 11809) found in the wall of Hoare Abbey, Co. Tipperary, c. 1830'.

${ }^{9}$ P. de Brún, Scriptural Instruction in the Vernacular. The Irish Bible Society and its Teachers 1818-1827 (Dublin, 2009), 11-13, 30-31.
} 
Adam Clarke in the 1820s and was offered for sale with his other manuscripts (1835 Clarke 162); McQuige's copy, now G 36, was also offered in the same sale (1835 Clarke 171). Both went via the dealer Thomas Thorpe to Sir Thomas Phillipps. I am certain that the note on TCD MS 2068 is not in McQuige's hand, though it may well be a little older than the note in Add. 11809, albeit in the latter case the location of Hore abbey was correctly given, while the note on MS 2068 places it in the wrong county. I have been unable to explain the link that has caused these two notes to refer in their different ways to a provenance from the walls of the same abbey. Perhaps there was a story going round.

Rather than regard these notes as evidence of two more manuscripts with such finding-stories, we may rather look on them as two more cases of the story associated, possibly at random, with medieval manuscripts.

An exotic example of the theme appears in NLI MS G 1417, offering an English translation of text from a recently discovered item in Irish: ${ }^{10}$

The Vision of Melachlin O Phelan King of Decies an Irish manuscript above 600 yrs old Discovered on the 29th Day of August last $\backslash 1817 /$ in the Earthern Urn by 2 peasants as They ware diging up the remains of an old limekill in a field in the vicinity of Cork Translated by a Rernd Gentleman Eminent for his Learning and piety and Perfectly Skilled in the Accidents of the Irish language. Mr Thornhill the proprietor of the Irish manuscript begs leave to advance as a caution that should any person presume to print or Sell a copy of this Translation unless Duley authorized they Shall be Dealt with According to Law.

The scribe was Patrick Ryan, Drumclieve (Co. Tipperary), 1817-18, so that recent discovery was implied. The year 1817 was added above the word 'last' as interpretation. The source, however, as Pádraig Ó Macháin notes, was a halfsheet booklet, printed, most likely in Cork, in 1816. One copy of this item is known. ${ }^{11}$ The caution is not part of the booklet. The surname Thornhill occurs among the gentry of Co. Cork, but we may doubt whether identification of $\mathrm{Mr}$ Thornhill will provide a context. The tract is contemporary prophecy, using the name of Maeleachlainn Ó Faeláin, ruler of the Déisi, who was captured by Strongbow following the siege of Waterford. In the vision St Patrick held up a roll, upon which Melachlin read a prayer of expiation; he was told, 'Go write upon a paper of vellum, and in a vessel of porcelain bury the same in the womb of the earth. And when it is the will of the High One, he shall bring it forth, as a light unto the ungodly in the day of temptation and darkness'. The vision pointed towards change in 1818 . There was no ancient manuscript, and it must be suspected that the buried urns represent the exercise of archaeological imagination in the years after the finding of the Book of Lismore.

\footnotetext{
${ }^{10}$ P. Ó Macháin, 'A Tipperary emigrant's manuscript', Tipperary Historical Journal (2013), 96-108.

${ }^{11}$ NLI Dix Cork 1816 (1). Another copy belonged to Thomas Crofton Croker (1798-1854) and appeared in the sale of his library. The titlepage reads: The Vision of Melachlin O'Phelan, King of Decies, an Irish Manuscript, (Above 600 Years Old,) discovered on the 29th day of Aug. last, in an earthern urn, by two peasants, as they were digging up the remains of an old lime-kiln in a field in the vicinity of Cork. - Translated by a Reverend Gentleman, eminent for his learning and piety, and perfectly skilled in the accidence of the Irish language. Price 10d. 1816.
} 
More challenging is a sixteenth-century source concerning Richard FitzRalph (d. 1360), an international churchman, familiar with the papal court in Avignon, who was consecrated archbishop of Armagh in $1344 .{ }^{12}$ The source is John Bale (1495-1563), a former Carmelite friar who in the 1530s became a vitriolic reformer, and who was nominated to the see of Ossory in 1552 by the Calvinist government of the young king Edward VI. He spent about six months in Ireland. The king's death and the accession of Queen Mary saw the restoration of Catholicism, and Bale, in fear of the stake, exiled himself to Basel. In a book published there in February 1559, and ingratiatingly dedicated to the new queen Elizabeth, he writes: ${ }^{13}$

Ricardus iste nouum Christi Testamentum in Hybernico sermone (a se fortassis translatum) anno uno aut altero ante suam mortem, in quodam ecclesiae suae muro occultauit: in cuius fine, quasi prophetizans, hoc scripsit: Cum hic liber inuentus fuerit, ueritas toti mundo manifestabitur, uel Christus orbi mox apparebit. Et repertus est ille liber circa annum a nato Seruatore 1530, in reparatione eiusdem ecclesiae.

This Richard [FitzRalph] concealed a copy of Christ's New Testament in the Irish language (perhaps his own translation) in a wall of his church, a year or two before his death. At the end of his life, as if to prophesy, he wrote this: When this book is found, truth will be revealed to the whole earth or Christ will soon appear to the world. And that book was found around the year $1530 \mathrm{AD}$ when the same church was repaired.

Archbishop Ralph's church was Armagh cathedral, where he is thought to have been a canon-perhaps rarely in residence-before the chapter elected him archbishop. In Ireland he was in dispute with the church of Dublin, keen to snatch the primatial role, and he was also engaged in controversies outside Ireland for long periods. He died at Avignon in November 1360, and his remains were later brought back to Ireland as part of an unsuccessful campaign for his canonization in his home town of Dundalk. The story can have no connexion with him or his interests, but it seems possible that it was something Bishop Bale had heard in 1552-3. It has the flavour of a reformer's story, promoting the reading of the New Testament in the vernacular, and the date of its finding coincides with the first impact of the Reformation in Ireland. We might imagine that it was Bale's own fiction, though there are no parallels for it in his background. It may be better viewed as a story among protestants in Ireland, still told during Bale's brief sojourn in the country. Bale's book was the second volume of a catalogue of writers from Great Britain, and at the end of it he adds a few writers from Ireland. FitzRalph's career and writings had already been treated in the first volume. ${ }^{14}$ The repetition adds nothing of substance, but a short aside follows, in which Bale quotes a comment about FitzRalph from a work recently published, also in Basel, by Matthias Flacius, a

\footnotetext{
${ }_{12}$ K. Walsh, A Fourteenth-Century Scholar and Primate: Richard FitzRalph in Oxford, Avignon, and Armagh (Oxford, 1981).

13 John Bale, Scriptorum illustrium maioris Brytanniae posterior pars (Basel, 1559), 245.

14 John Bale, Scriptorum illustrium maioris Brytanniae Catalogus (Basel, 1557), 443-5.

There it was said that some claimed him as English, others as Irish.
} 
reform theologian from Croatia, then teaching in Germany. ${ }^{15}$ Bale then adds the story quoted above and comments on the four provinces of Ireland and the four archbishoprics. The remark, therefore, is most likely to stem from his own experience in Ireland. James Ussher took exactly the words of our quotation as the peg on which to enter Richard FitzRalph in his list of vernacular versions under the year 1358, a date deduced from Bale. ${ }^{16}$ Ussher further cites John Foxe as saying that FitzRalph had translated the bible into Irish: 'I credibly heare of certayne old Irish Bibles translated long synce into the Irysh tong, which if it be true, it is not other lyke, but to be the doing of this Armachanus'.$^{17}$ (Had Foxe met Bale, one wonders, who was based at Canterbury from 1560, when he returned from exile, to his death in 1563?) Ussher himself adds, 'Hujusmodi Bibliorum fragmenta in Hibernia passim extant', which he can hardly have justified to himself. As Christopher Anderson put it in 1828, with regard to FitzRalph, 'No vestige of this translation is supposed to be now in existence'. ${ }^{18} \mathrm{~T}$. K. Abbott allowed that Latin manuscripts in an Irish hand may have been mistaken for Irish, as, he says, happened with the Book of Dimma. ${ }^{19}$ A glance at the flyleaves removed from a Lanthony manuscript, now in Lambeth Palace Library, which was presumably bound in Ireland where the priory had a cell at Duleek, one can see how confusion might arise towards the end of the middle ages, but why should someone who could not tell Latin from Irish presume that the text was biblical ${ }^{20}$ It is not easy to believe that anything was found in any wall at Armagh around 1530, but between then and 1553 a story was in circulation that long anticipates those we have discussed from the nineteenth century and later.

\footnotetext{
${ }^{15}$ M. Flacius Illyricus [Matija Vlačić], Catalogus testium ueritatis, qui ante nostram aetatem reclamarunt papae (Basel, 1556), 919-20. Bale ignores Flacius's remark that he had erroneously made FitzRalph a cardinal as well as an archbishop.

${ }^{16}$ J. Ussher, Historia Dogmatica Controversiae inter Orthodoxos et Pontificios de Scripturis et Sacris Vernaculis, ed. H. Wharton (London, 1689), 156. On p. 155 Ussher's reference under 1290 to copies of the bible in English older than Wyclif's translation is well known; it derived from Thomas James. H. A. Kelly, The Middle English Bible. A Reassessment (Philadelphia, PA, 2016), 3-4, $225 \mathrm{nn} .22,23$.

${ }^{17}$ Ussher refers to J. Foxe, Actes and Monuments (London, 1596), 381, citing the fifth edition. Thanks to the website John Foxe's The Acts and Monuments Online, I can say that the statement occurs in this form (though not always in this spelling) in the editions of 1570, p. 532 (quoted); 1576, p. 434; and 1583, p. 438. It is not found in the first edition of 1563.

18 Bale, Foxe, and Ussher are all cited on these points by Christopher Anderson in his account of the bible in Ireland, Memorial on behalf of the Native Irish (London, 1815), 1314; id. Historical Sketches of the Native Irish and their Descendants (Edinburgh, 1828), 18, and in the enlarged edition, (Edinburgh, 1830), 46-7, and by John Quigley, 'The history of the Irish bible', Irish Church Quarterly 10 (1917), 49-69 (p. 49).

19 T. K. Abbot, 'On the history of the Irish Bible', Hermathena 17 (No. 38, 1912), 29-50 (at p. 29).

${ }^{20}$ Photographs in L. Bieler and J. P. Carney, 'The Lambeth commentary', Ériu 23 (1972), 155. The leaves were removed from the binding of Lambeth Palace, MS 119, a late-twelfthcentury copy of a commentary on Revelation, ascribed to John, subprior of Lanthony (Gloucs), and listed in the fourteenth-century library catalogue of Lanthony as 'Iohannes supprior super apocalipsim. Magnum volumen' (A16. 132).
} 